\title{
TrADUÇấo
}

\section{A AMPLIFICAÇÃO NOS PROCESSOS DE INFORMAÇÃO ${ }^{1}$}

\section{Gilbert Simondon}

Tradução de Pedro Peixoto Ferreira ${ }^{2}$ e Evandro Smarieri ${ }^{3}$

\begin{abstract}
Resumo: Esta é a tradução do texto "L'amplification dans les processus d'information", conferência ministrada por Gilbert Simondon em 1962, no Colloque de Royaumont sobre "o conceito de informaçáo na ciência contemporânea (Le concept d'information dans la science contemporaine). Aqui Simondon apresenta, e correlaciona, três "níveis do processo informacional de amplificação": a amplificação transdutiva "por recrutamento positivo"; a amplificação moduladora "por limitação"; e a amplificação organizadora "por descoberta de um sistema de compatibilidade". Para cada um dos três níveis, Simondon apresenta exemplos dos mundos físico, vivo, técnico e psicossocial.
\end{abstract}

Palavras-Chave: Gilbert Simondon, informação, amplificação, transdução, modulação, organização.

\section{INTRODUÇÃO: A METAESTABILIDADE DO RECEPTOR É A CONDIÇÃO DE EFICÁCIA DA INFORMAÇÃO INCIDENTE}

Ser ou não ser informação não depende somente de características internas de uma estrutura; a informação não é uma coisa, mas a operação de uma coisa ingressando num sistema, e nele produzindo uma transformação. A

${ }^{1}$ Tradução de "L'amplification dans les processus d'information." Texto da conferência ministrada em 1962, no Colloque de Royaumont sobre Le concept d'information dans la science contemporaine, do qual Gilbert Simondon foi o organizador. Apenas o seu resumo foi publicado nos Anais. Publicado na íntegra em SIMONDON, G. Communication et information: cours et conférences. Chatou: Les Éditions de la Transparence, 2010, p.157-176.

${ }^{2}$ Professor do Departamento de Sociologia (DS) do Instituto de Filosofia e Ciências Humanas (IFCH) da Universidade Estadual de Campinas (Unicamp). Coordenador do Laboratório de Sociologia dos Processos de Associação (LaSPA/CTeMe). ORCID: https://orcid.org/0000-0001-6955-8414. E-mail: ppf@unicamp.br

3 Doutorando em Sociologia pela Universidade Estadual de Campinas - UNICAMP. (iD https:// orcid.org/0000-0002-8699-4813. E-mail: esmasoares@gmail.com

http://dx.doi.org/10.1590/0101-3173.2020.v43n1.16.p283 
informação não pode ser definida fora desse ato de incidência transformadora e da operaçáo de recepçáo. Náo é o emissor que faz de uma estrutura uma informação, pois uma estrutura pode se comportar como informação com relação a um receptor dado, sem ter sido composta por um emissor individualizado e organizado; impulsóes provenientes de fenômenos aleatórios podem disparar um dado receptor, da mesma forma como as provenientes de um emissor (cf. o sinal interferente, o ruído, a interferência e o QRM). ${ }^{4}$ Em contraposição, os sinais emitidos por um emissor resultam apenas na degradação de sua energia portadora, se eles não encontrarem um ou mais receptores nos quais eles desempenhem um papel eficaz, determinando as mudanças de estado que não poderiam ocorrer sem a incidência dos sinais: a realidade local, o receptor, é modificado em seu devir pela realidade incidente, e é essa modificação da realidade local pela realidade incidente que é a função da informaçáo. É virtualmente receptora toda realidade que não possui inteiramente nela mesma a determinação do curso de seu devir. Essa condiçáo é realizada se o receptor não é completamente um sistema, isto é, se, de um lado, ele possui um nível de organização elevado (com isolamentos internos e uma distribuição não-aleatória de seus elementos, permitindo-lhe reter uma energia potencial capaz de operar transformaçóes futuras), e se, de outro lado, a mudança de estado possível pelo jogo da energia potencial não depende de fatores internos, locais.

O receptor é uma realidade autônoma, do ponto de vista energético, pois ele possui a energia potencial (energia de estado) capaz de garantir transformaçôes, de as alimentar; mas o receptor não é efetivamente um receptor, se não for heterônomo do ponto de vista da causa que dispara as transformaçóes - essa causa disparadora sendo um aporte de energia incidente, eventualmente táo fraco quanto se queira. Por isso (autonomia energética e heteronomia da disparação das transformaçóes por mudança de estado), um receptor é um quase-sistema, um sistema de entrada. Com efeito, o conceito físico de sistemas acoplados - aplicado a um receptor e a um emissor - não permite dar conta, com precisão, da função de informação: a energia fraca incidente do sinal não entra diretamente em relação com a energia potencial do receptor; aquela náo se acrescenta a esta, nem a subtrai, náo se encontra no trabalho produzido na saída do receptor terminando em um efetor; ela age como "causa ocasional" e pode iniciar a mudança de estado do receptor por uma modificaçáo da estrutura de isolamentos internos do receptor, sem

${ }^{4}$ Código de rádio que significa: "Está com interferência?" 
acrescentar nada à sua energia potencial. Este é o caso de um tríodo, no qual uma impulsão faz a grade de comando passar de uma tensão fortemente negativa (cut-off) a uma tensão nula com relação ao cátodo; a mudança por impulsão incidente equivale a uma mudança de estrutura do tríodo por supressão da grade de comando; o tríodo se torna aqui comparável a um díodo possuindo o mesmo ânodo e o mesmo cátodo. Uma tal mudança de estrutura não implica troca reversível de energia entre os dois sistemas, mesmo fracamente acoplados: a incidência de informação não é um acoplamento.

O receptor de informação é uma realidade que possui uma zona mista de interação entre as estruturas ou energias locais e os aportes de energia incidente; se essa zona mista de interação estiver em relação com a existência de estados metaestáveis, ela conferirá à informação incidente sua eficácia, isto é, a capacidade de iniciar, no receptor, transformaçôes que não seriam produzidas nele espontaneamente apenas pelo jogo de fatores locais.

A irreversibilidade da relação entre a realidade incidente e a realidade local repousa sobre a metaestabilidade inicial do estado do receptor antes da recepção da informação. Essa metaestabilidade garante a autonomia energética do devir do receptor. Se o receptor estivesse em estado estável no momento em que recebesse a realidade incidente, ele não poderia ser modificado sem acoplamento reversível com um outro sistema: a entrada do receptor seria também uma saída efetora. É a metaestabilidade do estado do receptor que mantém a distinção funcional entre entrada e saída; antes de serem organologicamente distintas, entrada e saída são os termos extremos de uma transformação não-reversível, na qual a entrada é a operação de informação por incidência em uma realidade em estado metaestável, e a saída é o efeito produzido no final da transformaçáo da energia potencial desse estado metaestável, desencadeada pela incidência de informaçáo.

\section{A amplificaÇấo transdutiva}

O modo mais elementar da operação de informação que coloca em funcionamento a metaestabilidade do receptor é a amplificação transdutiva. Ela pode ser encontrada particularmente nas soluçôes supersaturadas ou nos líquidos em estado de sobrefusáo. Quando se introduz um germe cristalino microscópico numa tal solução, a cristalizaçáo se produz por amplificação, a partir do ponto onde o germe foi introduzido. De maneira controlada, pode-se obter assim um monocristal de tamanho considerável, pesando talvez muitos quilos, a partir 
de um germe constituído de apenas algumas moléculas. A solução em estado metaestável constitui aqui um receptor; a introdução de um germe é uma incidência de informação, uma entrada, que dispara uma mudança de estado (aqui uma mudança de fase) e faz passar o receptor do estado metaestável ao estado estável. A incidência de informação pode, aliás, nesse caso, ser realizada por um processo aleatório (introdução de uma poeira, perturbação provocada em um ponto da solução); o germe cristalino pode não ser constituído pela espécie química que constitui a solução metaestável, bastando que a espécie cristalize no mesmo sistema (sincristalização; ver também a forma de cristalização do enxofre - de marrom, líquido, a amarelo, sólido).

Um tal processo de amplificação progride indefinidamente: cada camada do cristal já constituído serve de sinal para a solução supersaturada imediatamente vizinha, e a faz cristalizar: é gradualmente, no limite progressivo do cristal em vias de se "nutrir" na sua "água-mãe", que a informação se transmite: a função entrada e a função saída se propagam, recrutando progressivamente toda a energia potencial da solução primitiva, até a estabilidade final. É essa transferência gradual, alimentada energeticamente pela mudança de estado no próprio local onde se produz a transformação, que se pode nomear transdução. Esse processo, tomado aqui num caso elementar, é distinto da transmissão de uma informação sob forma de propagação de uma perturbação mecânica ou eletromagnética; na transmissão, o campo atravessado não é receptor, ele não substitui energeticamente a incidência de informação e não muda o regime de equilíbrio.

A propagação do influxo nervoso é de tipo transdutivo; no estado de repouso, existe uma polarização que a estimulação destrói localmente; essa destruição local desencadeia a despolarização da zona imediatamente vizinha e aquela, por sua vez, tendo mudado de estado (pela passagem do metaestável ao estável), desencadeia a zona seguinte. Um tal processo foi realizado sob forma de modelo macroscópico eletroquímico por Lillie. Notemos que o local de incidência basta para determinar funcionalmente a entrada e o sentido da propagação da onda de mudança de estado. Diferentemente do que há tempos se acreditou, um axônio conduz nos dois sentidos, mas se ele for estimulado na sua extremidade periférica, a onda de mudança de estado só pode percorrêlo em um sentido; os termos extremos da propagação transdutiva são, entâo, entrada e saída, sem comportar necessariamente um privilégio organológico. $\mathrm{O}$ mesmo ocorre no modelo de Lillie, desde que se suprima o efeito da mudança de estado transmitido não-transdutivamente (por conduçáo elétrica no metal, 
o que muda a polarização com relação ao meio sobre toda a extensão, desde o momento em que o ataque do metal começa em um ponto). Há, assim, amplificação da operação inicial de incidência despolarizante pela iteração indefinida ao longo de todo o receptor.

Os modelos tecnológicos que empregam um processo transdutivo supóem a possibilidade de uma reação em cadeia a qual se propaga gradualmente; segundo a estrutura inicial mais ou menos limitante, a propagação ganha um aspecto de transferência aditiva ou multiplicativa, segundo o modelo da linha, da superfície e do volume, sendo a entrada somente um ponto. A propagaçáo transdutiva da combustão em um pavio Bickford é uma transferência aditiva, assim como a propagaçấo da onda explosiva em um cilindro contendo um mistura detonante; ao contrário, a propagação de um incêndio de floresta, a partir de um foco, é uma transferência multiplicativa segundo o modelo da superfície; enfim, a propagação da reação química em um volume de explosivo, a partir de um ponto central de ignição, é uma transferência multiplicativa segundo o modelo do volume. $\mathrm{O}$ fenômeno permanece informacional, mesmo se a ligação entre os elementos se faz por intermédio de uma transmissão, desde que essa transmissão seja apenas a expressão da mudança de estado do elemento anterior. Assim, um fogo na floresta se propaga transdutivamente, mesmo se cada árvore queimada emita ao seu redor pinhas e faíscas que vão comunicar o fogo às árvores vizinhas: é preciso que a árvore em chamas tenha mudado de estado, tenha entrado em combustão com o ar ambiente, para emitir assim os elementos que transportam o fogo adiante; e é preciso que esses elementos transmitidos sejam recebidos pelas outras árvores em estado metaestável (secas, arejadas), para que a operação transdutiva continue; as transmissóes intermediárias entre os elementos transdutivos, mudando de estado, autorizam, apenas, uma maior distância entre elementos; eles podem também, se acumularem energia, causar um atraso na propagação, conservando mesmo assim o esquema fundamental da amplificação transdutiva.

Esse modelo se aplica aos processos psicossociais; em certo sentido, ele permite defini-los, pois os fenômenos psicossociais são psíquicos, por terem como entrada uma incidência de tipo psíquica, individual; mas eles são sociais, pois se propagam por amplificação transdutiva, o que os faz passar da dimensão individual de entrada à dimensão coletiva de saída. Com efeito, os fenômenos puramente psíquicos são aqueles que se produzem no indivíduo sem modificar seu estado de equilíbrio, sem desencadear nele uma transformação que se traduza por uma atitude percebida como nova e significativa para um outro 
indivíduo. É informação a incidência que, em um grupo dado, conduz a uma mudança de equilíbrio em um certo número de indivíduos, que, pelo próprio resultado de sua mudança, desencadeia uma mudança em outros indivíduos potencializados de maneira análoga. A condição primeira é a existência, em um grande número de indivíduos, de uma metaestabilidade inicial, predeterminando seletivamente a categoria de incidências que podem desempenhar um papel eficaz de desencadeamento. Os estados tensos - medo, inquietude, esperança de transformaçáo - são, muito geralmente, o equivalente psíquico dos regimes físicos de metaestabilidade; o estado de alienação coletivamente experimentado é a condição de possibilidade dos fenômenos psicossociais, pois eles alimentam energeticamente a transdução amplificadora pela qual se opera [no caso físico] a passagem da incidência do germe cristalino microscópico à mudança de estado macrofísico do conjunto da soluçáo supersaturada ou sobrefundida. No caso do fenômeno psicossocial, o ato de incidência constitui a entrada pelo próprio fato de a amplificaçáo transdutiva ser efetivamente desencadeada, e náo por um privilégio institucional: o boato pode ser mais eficaz do que o anúncio, mesmo que o anúncio se beneficie de importantes meios de transmissão hertziana ou da imprensa de grande tiragem.

Um caráter essencial da propagação transdutiva é a existência de um limiar de desencadeamento e de um caráter quântico de funcionamento, procedendo por tudo-ou-nada e implicando, após cada mudança de estado, um período refratário (ou tempo de recuperação), durante o qual nenhuma incidência de informação é eficaz. Esse recovery time, bastante variável segundo os domínios, é a característica mais importante a se conhecer, para a previsão das mudanças nos processos psicossociais; ele permite definir uma verdadeira constante de tempo de cada efeito psicossocial, que governa e condiciona todos os processos mais complexos, implicando propagaçóes transdutivas: autorregulação, adaptação, ajustamento de níveis, oscilaçôes. O tempo de recuperação, para a fibra nervosa, é da ordem do milésimo de segundo; nos fenômenos psicossociais (atitudes étnicas, sentimentos nacionais), ele pode chegar a semanas ou mesmo anos. Entretanto, os fenômenos psicossociais são geralmente mais rápidos do que os fenômenos sociais, pois eles não exigem, para existir, uma modificação das condiçóes de base (produção, desenvolvimento industrial, população, tipo de educação), mas apenas um acionamento de reservas energéticas já potencializadas, imediatamente disponíveis; no domínio psicossocial, "tudo é possível”, quando o estado das tensôes permite uma propagação transdutiva; mas as tensôes são seletivas; nem toda incidência é, para elas, uma informação eficaz, determinante; além disso, a incidência informacional deve se apresentar 
no momento certo, pois a ativação de tensôes não é indefinidamente disponível: a eficácia da informação requer condiçóes de estrutura (de conteúdo) e condiçóes de oportunidade da incidência. "Tudo é possível" no domínio psicossocial, mas não em qualquer lugar, em qualquer momento ou de qualquer forma. Além disso, nem tudo é psicossocial: a realidade psicossocial, precisamente por se alimentar de energias acumuladas, as utiliza e as esgota; ela é um intermediário necessário entre o individual e o social, mas esse processo de passagem, de mudança de nível, de passagem do microscópico ao macroscópico é, por sua própria natureza, momentâneo. Não há continuidade, se ele não se traduz por um efeito institucional no nível de estruturas sociais. Os fenômenos psicossociais são essencialmente informacionais. Eles não são feitos de atitudes, mas de mudanças de atitudes; uma atitude, como fenômeno psicossocial, é uma relação interindividual em transformação.

\section{A AMPLIFICAÇÃO MODULADORA}

O esquema da amplificação moduladora é obtido domesticando-se a propagação transdutiva; isto é, dominando-a e a alimentado localmente, para fazê-la produzir e trabalhar em condições regulares. $\mathrm{Na}$ transdução, o fenômeno de basculamento, de passagem da metaestabilidade à estabilidade, muda constantemente de suporte, ao avançar; na modulação, o local de passagem do estado energético metaestável ao estável é fixo: uma fonte de energia potencial (power supply) está aguardando e pode agir por meio de um efetor sobre uma carga; a energia não é mais contida em estado difuso na metaestabilidade do estado inicial do receptor, ela é contida por um dispositivo de alimentação que forma um quase-sistema com o efetor, agindo sobre a carga; enfim, a entrada intervém como incidência no hiato desse quase-sistema (preferimos esse termo àquele de Bertalanffy: sistema aberto); entre alimentação e saida do efetor sobre a carga, existe a entrada. A entrada age como um isolamento variável que se interpóe entre a fonte de energia e a carga; esse isolamento não acrescenta energia ao quase-sistema, tampouco a suprime; ele governa, controla o regime de mudança de estado de energia potencial, a cada instante, seja por escolha entre dois valores (tudo ou nada, regime pleno ou nulo, abertura ou fechamento do circuito reunindo a fonte de energia e a carga), seja por escolha entre uma infinidade de valores entre um máximo e um mínimo, entre a saturação e a interrupção. Nesse caso desde que não se evoque, como no tiratron, um processo transdutivo auxiliar (a ionização em cascata) -, a irreversibilidade do vetor causal, orientada da 
entrada para a saída, subsiste, mas o período refratário desaparece, pois a fonte de energia é agora exterior ao local onde se realiza a passagem da energia potencial a um trabalho: essa permanente disponibilidade de energia potencial, independente do trabalho já realizado ou em vias de se realizar, equivale à conservação de uma permanente metaestabilidade. $\mathrm{O}$ modulador está constantemente em vias de decidir a partir da incidência de informação; essa incidência de informação governa, instante por instante, o regime de transformação de energia potencial em trabalho.

O modulador é um amplificador sem iteração ou processo de multiplicação, pois ele coloca em jogo uma relação entre termos extremos de uma série energética incidente e de uma série local, ao realizar, num espaço privilegiado, uma equivalência entre esses termos extremos. Se tomarmos, por exemplo, o caso de um tríodo de cátodo quente, o espaço privilegiado de equivalência é aquele compreendido entre o cátodo e a grade de comando. Funcionalmente, esse espaço pertence ao circuito de grande energia que reúne os polos opostos da fonte de corrente anódica, passando pelo efetor de saída (resistência, motor, primário do transformador), em série com o espaço compreendido entre cátodo e ânodo, no interior do tríodo. A diferença de potencial entre os polos da fonte de alimentação anódica cria, através da carga do efetor, uma diferença de potencial entre cátodo e ânodo. Agindo sozinha, essa diferença de potencial (enquanto o cátodo está quente, e se a diferença de potencial for suficiente) cria uma corrente no interior do tríodo, que é a corrente de saturação. Mas o termo extremo inicial da transferência - sob a influência desse campo elétrico entre cátodo e ânodo, dos elétrons emitidos pelo cátodo - interfere entre cátodo e grade com o termo extremo final da incidência: é a diferença de potencial com relação ao cátodo que cria, sobre a grade de comando, a entrada de sinais de informação; a grade, nesse espaço privilegiado e superdeterminado, cria, ela também, um campo elétrico, assim como o ânodo; e a sua maior proximidade com relação ao cátodo confere à incidência uma função de alavanca com relação ao regime da corrente anódica, considerada como estando sob a dependência composta e antagônica da tensão do ânodo e da tensão da grade, ambos relativamente ao cátodo. Se supusermos que a tensão do ânodo não é suficiente na origem para alcançar a saturação, o consumo eletrônico permanece sob a dependência da tensão do ânodo, com uma relação tensão/corrente definida; ora, quanto mais a grade for aproximada do cátodo, levando-se em conta a distância entre cátodo e ânodo, mais é suficiente uma fraca variação da tensão da grade, para provocar a mesma modificação de intensidade anódica que uma variação determinada 
da tensão do ânodo; é este o efeito de alavanca exercido pelas variaçóes de tensão da grade sobre o consumo anódico no qual, no entanto, a origem energética permanece sendo a fonte de alimentação anódica. Uma variação de tensão muito pequena da grade tem o mesmo efeito que uma variação muito mais considerável da tensão do ânodo, porque a tensão do ânodo faz parte do quase-sistema, enquanto a tensão da grade é aquilo que intervém no hiato desse quase-sistema, como incidência; o modulador é um dispositivo que permite a irreversibilidade, não graças à passagem da metaestabilidade à estabilidade do receptor, mas porque uma diferenciação funcional e organológica permite ao termo extremo de uma série incidente equivaler, num pequeno espaço privilegiado, ao termo inicial de uma série local, eventualmente muito mais potente que a série incidente.

A criação dessa equivalência no espaço privilegiado de interferência funcional resulta da colocação, em presença, de um termo final fraco e de um termo inicial potente; a equivalência é possível, pois o termo inicial da série local está ainda muito próximo do seu ponto de origem; pôde, até entáo, fornecer muito pouco trabalho, adquiriu muito pouca energia cinética: a queda de potencial da qual se beneficiaram os elétrons saídos do cátodo é muito fraca no nível da grade de comando; quanto mais fraca for essa transformaçáo, da energia potencial local em energia cinética e em energia atual (juntas/somadas [ajout]) no espaço privilegiado, mais é elevada a eficácia da incidência; é por isso que se emprega, nas válvulas de cátodo quente, uma polarização negativa da grade. Quanto à energia de sinais incidentes vindo modificar o potencial da grade, ela é a última etapa de uma série, talvez longa, de transformaçóes e de transmissóes, portando energia de outro lugar; essa energia não está mais em forma potencial; a modificação do potencial da grade é a última etapa: a série incidente, antes de se esgotar, controla por seu último termo a série local nascente, que, por sua vez, poderá controlar, como portadora de informação, num outro nível de modulação amplificadora, uma nova série energética.

Podemos nomear essa estrutura como estrutura de relé, por analogia com a relaçáo de termos extremos finais e iniciais que existe entre o curso de um primeiro indivíduo, chegando esgotado no final da sua rota, e aquele do segundo que, tendo esperado, parte somente após a chegada do primeiro, com toda a reserva energética que lhe permitirá completar sua rota: a chegada do indivíduo incidente controla a partida do indivíduo seguinte e poderia também controlar a partida de uma numerosa equipe. Pode-se dizer que o receptor é mais jovem em seu devir do que a informação incidente; a informação é o 
último termo de uma série; a modulação amplificadora em um relé é também uma troca entre ciclos de existência; a realidade incidente é mais velha do que a realidade local. Nesse sentido, pelo aporte de energia potencial, o relé realiza uma regeneração. A amplificação moduladora é um recomeço, a passagem a uma nova etapa.

Os modelos tecnológicos de amplificação moduladora são numerosos; um tríodo de cátodo quente, um transistor, são amplificadores-moduladores, nas montagens em que um sinal incidente de fraca energia controla uma energia local mais considerável. Pode-se realizar montagens moduladoras náoamplificadoras, quando se trata somente de controlar uma certa espécie de energia por meio de uma outra, que age como portadora de informação; assim, a modulação anódica de um emissor de ondas hertzianas não é amplificadora; aqui, a energia fornecida pela corrente de baixa frequência se acrescenta parcialmente àquela fornecida pela fonte de alimentação anódica do nível modulado pelo ânodo; os moduladores de díodo não são amplificadores; não se pode, ademais, propriamente falando, considerá-los como relés (ver Stevens e Tucker, Modulators and Frequency Changers). Seria mesmo possível modular uma energia, fazendo variar a adaptação de impedância da carga, o que equivaleria a modular por controle do rendimento; esses sistemas não são amplificadores, pois eles não utilizam o termo extremo final da série de transformações incidentes para controlar, no seu nascimento, o termo extremo inicial de uma nova série local.

O esquema de amplificação moduladora pode ser transposto para o domínio biológico e também para o domínio social; ele permite dar conta dos funcionamentos nos quais um processo é estabilizado, apesar de variaçóes aleatórias da carga, por uma informação que exprima o nível do efeito sobre a carga e controle o regime do modulador em função desse nível. ${ }^{5} \mathrm{~A}$

\footnotetext{
${ }^{5}$ Um modo de amplificação existe elementarmente na estrutura de conflito: quando diversos germes de estruturação são lançados juntos num meio metaestável, cada um deles começa a induzir uma mudança que vai até os limites do campo disponível e que pode mesmo reconverter em benefício de sua própria estrutura, incorporar ao campo de sua própria transdução, o terreno que já foi estruturado por outros germes; nesse caso, todo o aporte constituído pelos diferentes domínios diversamente estruturados se torna um campo de expansão estrutural para o germe portador a estrutura que esgota mais completamente as possibilidades de mudança de estado da realidade metaestável; estruturaçóes prévias fracas (que não esgotam as possibilidades energéticas) reservam um aporte a estruturaçóes fortes. Particularmente, estruturas sociais antigas de modulação, mantidas por uma estrutura autoritária que emprega apenas uma parte da energia disponível e obtém um fraco rendimento, oferecem um terreno de expansão a uma estruturação transdutiva intensa, que empregue mais profundamente as reservas de energia, alcançando um resultado mais estável. $\mathrm{O}$ jogo, onde cada jogador porta a contribuição de sua aposta pessoal, é um modelo simples de amplificação transdutiva: a aposta está em estado
} 
autorregulação não passa, aliás, de um caso particular do funcionamento da amplificação moduladora. Esse caso é interessante, pois produz efeitos de estabilização na transformação [devenir], apesar das flutuaçôes do nível de carga; esses efeitos de homeostase também são encontrados nos organismos, sejam eles indivíduos vivos ou os corpos sociais. Aqui ainda intervém, em cada caso, uma constante de tempo característica do domínio; a autorregulação só pode ocorrer, se o retorno de informação da saída para a entrada é curto com relação à duração média de uma perturbação aleatória da carga que se deve corrigir; quanto maior for a defasagem entre a perturbação e o retorno da informação, mais será necessário reduzir o coeficiente de amplificação do modulador, para evitar a entrada em um regime de instabilidade. A teoria dos servomecanismos [asservissements], com os estudos de estabilidade (critério de Nyquist), poderia sem dúvida ser aplicada a todos os funcionamentos homeostáticos, quer biológicos, quer sociais. Mas, importa notar que a propriedade fundamental da amplificação moduladora não reside na autorregulação possível: ela reside no fato de que a regulação, autônoma ou heterônoma, só se pode efetuar por uma redução do regime que torna a informação eficaz. Essa redução do regime é realizada, nas montagens técnicas, pela polarização do modulador que, na ausência de qualquer sinal, reduz seu regime a uma fração de seu pleno regime de saturação. Tal é o efeito da tensão negativa que se impóe à grade de comando de um tríodo, na ausência de qualquer sinal; nessas condiçóes, um sinal de pequena amplitude com relação a essa tensão contínua prévia de polarização é eficaz, seja ele positivo, seja negativo; a montagem amplificadormodulador só é correta e fiel, se for polarizada; a grandeza da polarização deve exceder aquela do sinal incidente e ser, pelo menos, igual aos seus valores extremos, senão o modulador corta o sinal por cut-off ou saturaçáo.

Um grupo social, e também um organismo, possuem uma unidade funcional, pois os diferentes subconjuntos que os constituem admitem uma polarizaçáo comum, variando para todos ao mesmo tempo quando ela sofre reajustes. A unidade do grupo social repousa sobre a homogeneidade de

metaestável, durante a partida; a guerra é de mesma espécie, particularmente quando ela se torna um vasto conflito: o vencedor encontra um vasto campo de expansão a estruturar, se as metaestabilidades que nele são contidas náo forem refratárias aos germes estruturais que ele porta; no jogo, a aposta, sendo em dinheiro, é sempre homogênea às possibilidades estruturais do vencedor; no conflito, o vencedor nem sempre pode estruturar transdutivamente o domínio que ele conquistou; nesse caso, ele se contenta em modulá-lo autoritariamente, impondo-lhe as estruturas que ele já utilizou em seu direito e em suas instituiçóes; mas ele chega assim a uma inibição, a um fraco rendimento, e as energias não empregadas constituem uma metaestabilidade residual que permite a constituiçấo de movimentos psicossociais que interrompam a modulaçáo assimiladora e autoritária. $\mathrm{O}$ acesso à independência dos povos colonizados apresenta essa passagem da modulação à transdução. 
normas de ação; ora, as normas não são, na grande generalidade dos casos, sinais ou conteúdos que desencadeiam por si próprios uma ação determinada, em um momento determinado, como um programa; antes, as normas são uma escala de valores a qual constitui a polarização prévia de cada membro do grupo, tornando-o capaz de apreciar uma informação determinada, um esquema de conduta, como uma grandeza positiva ou negativa com relaçáo a essa polarização inicial. Nesse sentido, uma moral se distingue de uma religião, por esta comportar um código, um conteúdo de sinais de ação, um programa de ação ritualizado, ao passo que uma moral é uma polarização sem programa, fornecendo uma escala de valores em cada circunstância, mas sem sequência programada, sem ritualização. Por sua própria natureza, sendo um programa, a escala de valores religiosa é rígida, fixa, enquanto aquela das morais é variável, podendo se modificar em função do regime médio dos acontecimentos.

Toda polarização, como todo sinal de informação recebido por um amplificador-modulador, resulta de um acontecimento ou de uma série de acontecimentos passados, parcialmente arcaicos no momento em que o modulador opera. Essa estrutura é um controle do regime atual da ação da energia potencial sobre uma carga em função de seu passado; e esse controle é tornado possível por uma diminuição da ação da energia potencial, por uma divisão da potência utilizável, graças à polarização que age como inibidor prévio; a incidência de um elemento do passado (informação) na ação presente do quase-sistema necessita, para ser eficaz, de uma diminuição da utilização da energia e do nível de atividade total. O ponto ótimo de estabilidade homeostática é distante do máximo das possibilidades de funcionamento do modulador e do pleno emprego do rendimento da energia potencial da fonte, devido às condiçôes de polarização. No domínio social, religióes e morais operam um regime permanente de limitação da atividade.

\section{A AMPLIFICAÇÁO ORGANIZADORA}

Um regime comum de transdução e de modulação pode se estabelecer, quando as decisôes sucessivas da transdução, em lugar de somente se desencadearem umas às outras, numa perpétua instantaneidade, se ordenam em série por meio de uma autorregulação: o recrutamento é, assim, orientado para um fim, em lugar de ser indefinido; cada decisão sucessiva leva em conta o efeito de decisóes precedentes: o domínio da transdução intervém como carga sobre a qual se opera um trabalho na sequência de decisóes sucessivas: há como 
que uma previsão do trabalho a ser realizado desde o início da transdução. A série transdutiva de decisóes é modulada por uma informação tomada sobre o conjunto do campo, que intervém, assim, como uma totalidade no percurso que o recobre e o transforma.

Um exemplo de amplificação organizadora é fornecido pela maneira como é recebida e integrada a informação visual na percepção binocular. As recepçóes periféricas fornecem imagens díspares sobre as retinas. Essa disparidade é feita, por um lado, da dualidade de pontos de vista, conduzindo a projeçóes retinianas não-sobreponíveis para um objeto único e, por outro lado, da diferença de recobrimento dos planos sucessivos. Consideradas como dados, as recepçôes retinianas são incompatíveis e não podem chegar a nenhuma correspondência, mesmo por empobrecimento abstrativo, pois elas não são sobreponíveis, nem parcialmente. Ora, são os próprios dados dessa incompatibilidade, no nível retiniano, que servem de motor organizador, de princípio de seriação, num sistema de compatibilidade de ordem mais elevada, onde todos os dados são remanejados e se reordenam segundo o relevo e a estruturaçáo sucessiva dos planos. $\mathrm{Na}$ imagem realmente percebida, todos os elementos que existem sobre cada uma das retinas se encontram presentes: não existe resto, nem detalhe eliminado. A tensão de incompatibilidade entre as duas imagens retinianas se torna seriação, organização compatibilizadora e totalizante, princípio dimensional de ordem mais elevada. Uma tal operação é uma resolução de problema. Aqui, a informação não é uma estrutura dada, mas um desenquadramento de estruturas, entre estruturas vizinhas, uma quase-identidade que exclui, no entanto, a superposiçáo e a identificação. A informação intervém como exigência, problema colocado, sistema de compatibilidade a ser inventado por passagem a uma axiomática dimensional mais elevada; é essa exigência que, aqui, controla; ela não é uma estrutura que se faz transmitir por uma energia nova, como no modulador polarizado.

A organização se torna possível por correlação de processos transdutivos e de processos moduladores. O processo transdutivo tem como efeito essencial permitir a mudança de ordem de grandeza de uma modificação, por passagem do elementar ao coletivo (o que chamamos de fenômeno psicossocial de amplificação por recrutamento, por meio da propagação gradual dos basculamentos em um meio metaestável); ele cria a homogeneidade final de todo o campo percorrido e realiza a ontogênese de uma macroestrutura, a partir de uma microestrutura-germe e de uma energia de estado macrofísico. A modulaçáo se exerce segundo a via complementar e inversa: estruturas 
macrofísicas carregadas por uma energia fraca governam o devir de uma população perpetuamente nova de elementos microfísicos determinados, muito próximos da origem de seu percurso livre, como a população de elétrons provenientes do cátodo quente da válvula a vácuo e submetidos, ao mesmo tempo, à ação do campo anódico (que continuará a se exercer de modo cada vez mais eficaz, ao longo do deslocamento) e do campo proveniente da grade, consequência derradeira de eventos chegando ao termo de sua realização. $\mathrm{O}$ controle da realidade nascente pela realidade antiga define o modo social do processo informacional: o modelo triódico [triodique] é o análogo funcional de uma estrutura social. Ora, há possibilidade de organização, quando há compatibilidade entre esses dois processos, segundo um modo de sintese real. A possibilidade aparece, quando o controle é exercido, não por uma só estrutura, mas por um grupo; em outras palavras, por um nó de tensão entre duas ou mais estruturas. A tomada de forma é realmente ininterrupta, feita de etapas encadeadas, mas essas etapas são simultaneamente significativas, do ponto de vista da organização; elas respondem a um problema modulador único, inteiramente dado, e, enquanto etapas de uma ação organizada, elas podem ser submetidas a uma transdução reversível; é na totalidade de seu encadeamento que uma ação possui sua significação, segundo uma forma de complexidade que implica memória e previsão.

Deve-se destacar que existem condiçôes comuns à consciência e à vida: o vivo está em relação com seu meio e, segundo a hipótese de Lamarck, uma invenção evolutiva se faz por incorporação ao organismo, sob formas e funçóes novas, de sequências de eventos que estavam antigamente sob a dependência do meio; o problema vital é resolvido por desenvolvimento do organismo, que absorve e estabiliza operaçóes anteriormente exteriores e aleatórias; aqui o problema colocado não é apenas feito de termos interiores ao ser vivo, mas de termos interiores e exteriores em relação complexa de correlação e de incompatibilidade parcial. Da mesma forma, a consciência não é feita apenas de conteúdos que a reenviam a ela mesma; ela consiste na correlação entre termos autógenos e alógenos; é esta a relação fundamentalmente problemática. A resolução do problema não é um simples arranjo de termos autógenos, mas um crescimento do campo da consciência, por meio da nova organizaçáo descoberta, tornando compatíveis, em um sistema dimensional mais vasto, os elementos antigos de interioridade e de exterioridade. A organização não é uma obra autárquica, nem para o organismo, nem para a consciência. Uma analogia funcional táo profunda deve conduzir a não separar vida e consciência como duas ordens estrangeiras [étrangers] uma à outra. É provável 
que, em certo nível de integração, problemas vitais só possam ser resolvidos por modalidades conscientes; nesse sentido, a consciência seria uma função vital, porque ela seria fonte de amplificação organizadora; em sentido inverso, nada me permite dizer que aspectos elementares da vida não sejam dados de consciência. Mas uma tal hipótese, que levaria a considerar a organização como a forma mais complexa de amplificação, incorporando ao mesmo tempo um processo transdutivo e um processo modulador, e os correlacionando funcionalmente, levaria também à consideração da resoluçáo de problemas vitais e psíquicos (portanto, à evolução e à invenção) como supondo, a título de base, a possibilidade anterior de aspectos sociais e psicossociais. Essa afirmação pode parecer paradoxal, mas ela não o é realmente, se se realiza uma extensão da noção de relaçôes sociais: moléculas, células elementares, podem estar, umas com relação às outras, numa relação de tipo social, implicando controle, modulação, redução da atividade; o fenômeno psicossocial é, então, somente a propagação transdutiva de uma perturbação que, tendo realizado uma mudança de equilíbrio no nível elementar, ressoa no nível coletivo por recrutamento de todos os elementos.

Talvez as grandes etapas filogenéticas tiveram por condição fenômenos sociais e psicossociais; assim, a noção de sociedade, inicialmente definida para o homem, se estende às espécies animais; mas ela pode ser mais completamente generalizada, englobar relaçóes entre vegetais e mesmo entre moléculas; da mesma forma, a relação de tipo psicossocial, definida inicialmente nas relaçóes interindividuais humanas, é suscetível de receber uma generalização. Então, poderíamos considerar que existe uma relação dialética entre a relação psicossocial, a relação social pura, e a relação de organização, aparecendo como síntese das duas primeiras: transdução, modulação e organização seriam os três níveis do processo informacional de amplificação por recrutamento positivo, por limitação e por descoberta de um sistema de compatibilidade. ${ }^{6}$

${ }^{6}$ Comparando-se um grupo social a um modulador, pode-se explicar parcialmente, por motivaçóes sociais, as escolhas sucessivas das direçốes de busca para as invençôes organizadoras: em cada época, e em cada civilizaçáo, é o tipo mais significativo de escassez sentida pelo modulador social que motiva a busca desinteressada. A Antiguidade greco-latina das civilizaçôes ocidentais manifesta essencialmente uma escassez de informaçóes incidentes; ela elaborou filosofias do saber, da sabedoria, representaçóes do mundo, metafísicas. Ao contrário, após a Renascença, o surgimento das ciências exatas satisfaz a falta de saber; mas, entre a informação e a ação eficaz sobre a carga, que é o mundo a transformar, existe um vasto hiato: a escassez é aquela de uma açáo eficaz, tấo segura e ordenada quanto o saber científico; assim, nasce a busca por uma metodologia técnica e humana de ação eficaz; o objeto mesmo é analisado como o resultado de uma ação construtiva, procedendo por etapas transdutivas ordenadas e operando uma transferência de força, de causalidade, de apoio ou de evidência; ele é uma longa cadeia, resultado de uma operação e possível instrumento futuro de operação. A dedução é um 


\section{CONSIDERAÇÓES FinaIS}

Se os três modos possíveis de amplificação são característicos de três tipos de relações em relação dialética, podemos perguntar, de início, se a relação dialética não é sempre o progresso, em três etapas, de um processo de amplificação inicialmente transdutivo, depois modulador e, enfim, organizador, devendo-se essa sucessão à mudança do domínio que realiza o exercício de um determinado tipo de amplificação.

Com efeito, a amplificação transdutiva é essencialmente positiva; ela não supôe nem isolamento, nem limite; ela é o modelo da operação positiva, que se alimenta dela mesma e se propaga pelo resultado instantâneo de seu próprio exercício: ela se afirma, porque causa perpetuamente sua própria capacidade de avançar; ela é autoposição, e não é autolimitada. Ao contrário, a modulaçáo supóe isolamento entre seus órgãos fundamentais: fonte de energia, entrada e saída do modulador; ela não é uma propagação autocondicionada, mas uma operação localizada [à poste fixe], que só é possível por uma inibição da atividade espontânea possível: ela se inscreve negativamente na atualização de uma energia potencial, e diminui o rendimento da transformaçáo possível. Em lugar de ser, como a transdução, movimento rumo à zona rica em energia potencial, a partir do domínio já estruturado, a modulação realiza uma submissão de uma série nascente do devir ao ato final de uma série anterior; ela determina o novo segundo a estrutura do antigo (ação de relé), o condiciona. Enquanto a transdução é orientada para o futuro, a modulação é uma vitória do antigo sobre o novo, uma reciclagem da estrutura antiga. A modulação é o ato crítico, redutor, no sentido próprio do termo; ela é o modelo do controle, da autoridade, no domínio social, assim como da operação destinada a evitar a variação fortuita, a detectar o erro. A organização corresponde à estabilidade do presente completo, dilatado em momento, etapa que condensa e mantém uma certa dimensão do passado e uma certa duração do futuro:

modo controlado de transdução sobre símbolos, enquanto os métodos analógicos, paradigmáticos da Antiguidade, são de tipo modulador. Enfim, a partir do século XIX, o desenvolvimento das técnicas de realização pôs fim à escassez metodológica de realização operatória: é então a energia potencial que falta para esses vastos conjuntos possuidores de saber e método operatório; a busca do power supply nas dimensōes das sociedades do século XIX conduziu o pensamento filosófico à descoberta das realidades motoras: motivaçóes humanas do socialismo, fontes naturais dos fisiocratas, exploração da natureza pelos homens em sociedade do marxismo. A filosofia do século XIX é, sob suas diferentes formas, uma filosofia da energia potencial; ela é a última etapa de uma evolução dialética. Com a noção de organização, a nossa [filosofia] começa um ciclo novo, onde se manifesta, como na Antiguidade, uma busca primordial de saber, de informaçáo que se possa inserir na entrada do modulador social ou psicossocial (coletivo). 
ela corresponde a um adensador de tempo, e de tempo presente, enquanto a transdução é um impulso instantâneo rumo ao futuro, e a modulação uma iteração fixa do passado sob forma de conservação. A ordem dessa sucessão é necessária, pois a modulação só pode ocorrer num domínio onde já existam estruturas; a transdução é precisamente capaz de criar estruturas a partir de um meio homogêneo metaestável.

Enfim, se a característica própria do psiquismo é a capacidade de organizaçáo, os atos de organização devem ser precedidos por operaçóes transdutivas e moduladoras que os preparam dialeticamente. Atividades instintivas em cadeia e processos de tipo associativo são essencialmente transdutivos. Ao contrário, as atividades de abstração e de generalização, controladas pelo raciocínio formal, aplicando esquemas adquiridos a conteúdos novos, são moduladoras. Enfim, os atos de invenção organizadora têm, ao mesmo tempo, a fecundidade dos processos associativos e a capacidade formalizadora da modulação.

FERREIRA, P. P.; SMARIERI, E. Translation of "L'amplification dans les processus d'information”. Trans/formlação, Marília, v. 43, n. 1, p. 283-300, Jan./Mar., 2020.

\begin{abstract}
This is a Portuguese translation of the paper "L'amplification dans les processus d'information", presented by Gilbert Simondon in 1962, at the Colloque de Royaumont about "the concept of information in contemporary science" (Le concept d'information dans la science contemporaine). In this paper, Simondon presents, and correlates, three "levels of the informational process of amplification": transductive amplification "by positive recruiting"; modulative amplification "by limitation"; and organizing amplification "by discovery of a system of compatibility". For each one of the three levels, Simondon presents examples of the physical, living, technical and psycho-social worlds.
\end{abstract}

KEYwORDs: Gilbert Simondon, information, amplification, transduction, modulation, organization.

Recebido: 29/08/2018

Aceito: 29/06/2019 
FERREIRA, P. P.; SMARIERI, E. 